\title{
Soft ERP and Hard ERP Implementation to the Integration System for Firm Performance
}

\author{
Zeplin Jiwa Husada Tarigan*, Sautma Ronni Basana, Widjojo Suprapto \\ Petra Christian University, Surabaya, Indonesia \\ * Corresponding author. Tel. +62312983244; email: zeplin@petra.ac.id \\ Manuscript submitted January 10, 2018; accepted June 1, 2018. \\ doi: 10.17706/ijeeee.2019.9.1.26-37
}

\begin{abstract}
Enterprise Resource Planning (ERP) packages are important for companies to integrate previously partial departments into one integrated system. This integrated system can incorporate data from various departments to facilitate decision making that fits the company's internal and external circumstances. The implementation of ERP in companies needs some people or key users who are able to work on the ERP system properly and correctly. The capabilities of the key users are related to soft ERP and hard ERP. Human-related abilities are called soft ERP while the equipment and tools are called hard ERP. Together, the soft ERP and hard ERP define the data integration in a company and become one entity in the well-being of communication among departments. The data for this research was collected using the likert scale. From the 100 questionnaires distributed to companies, there are 90 returned questionnaires or 90\% response rate. The data processing with Java Web Start software showed the result of positive significant impact of 0.643 from soft ERP to hard ERP. The Soft ERP has a positive and significant impact of 0.262 on integrated ERP. The Soft ERP has a direct influence of 0.281 on the company performance. The Hard ERP has a positive and significant impact of 0.439 on integrated ERP. The Hard ERP has a positive and significant impact of 0.375 on firm performance. The integrated ERP has a direct influence of 0.338 on company performance. Overall, the impact of the total variables of independent Soft ERP to company performance is equal to 0.706 . Therefore, the integration of ERP system brings positive and significant impacts to the business performance of manufacturing companies in East Java, Indonesia.
\end{abstract}

Key words: Soft ERP, hard ERP, system integration and firm performance.

\section{Introduction}

Enterprise Resource Planning or ERP is a data package that can integrate the data among departments in a company, where the data in the entry from the marketing department can be accessed by other departments that are related or connected with those data needed from the marketing. In implementing the ERP, a company has to go through several stages of introducing the ERP products or it can develop independently the ERP systems in accordance with the conditions of the company. The implementation of ERP in the company is inseparable from the understanding of the top management towards the objectives to be achieved through understanding the proper function of ERP [1]. The data package of ERP consists of software and hardware that can integrate any business process and function in order to present a business concept which blends business management and information technology concepts.

Based on some previous researches, there are many discussions on some critical success factors for ERP Implementation [1]-[4]. There are also several researches on ERP users [5]-[8]. The ERP implementation is 
also determined by the selection of software that will be used by the company when performing ERP [9]. ERP Implementation cannot be separated from the role of management in managing ERP by determining the team to run the implementation process so that data from one department can be integrated with data from other departments.

Many researchers have discussed the implementation of soft and hard ERP by running the project management. ERP is a project that is built by the management to be implemented well in a company. The project management is a combination of personnel, policies, procedures and systems (manual or with computer), that enables the implementation of planning, organizing, directing, and controlling project costs, schedule, quality and performance. The project management consists of some organizational subsystems which manage the human relation and the technical aspects (non-human). The management of technical aspect consists of the elements of planning system, controlling system, methodology system, and management information system [10]. The completion of a project depends heavily on the ability of the project manager to select the project to be done, the strategy for completing the project, the work method to complete the project, and a measurement system to monitor the project, to evaluate a project, and to declare the project completion [11]. One research states that hard aspects can be regarded as a technical problem in implementing a management project in a company while soft aspects is said to be a management problem [12]. The research conducted by Abdullah et al., [13] states that soft elements are related to the human aspect, while for hard elements are related to the equipment, process, measurement, and procedure design. The completion of an ERP implementation is inseparable from human or soft factors and IT based systems or hard factors [14]. Based on some observations and interviews of five manufacturing companies in East Java, the ERP implementation follows several stages, which start with the first stage: the initial evaluation. The initial evaluation phase is that the company decides to use an ERP system that suits the company's needs. This initial stage requires the company's management commitment to maintain the consistency with the decision to buy or create an ERP product that suits the needs of the company in improving the competitiveness of the company. The selection or evaluation process is one of the most important early stages in ERP implementation, because the chosen package will determine the success or failure of the project. This is because the ERP system involves a large investment. This first step should not fail, because it will dictate the next steps.

The second stage is the implementation phase of the ERP program in a company. At this stage, the company generally uses two consultant services. One consultant is an internal consultant who comes as a service from the ERP package purchased by the company, and another consultant is an external consultant who will modify the ERP system to the needs of the company business processes. At this stage, with the help of the vendor and ERP consultants, the ability of the project team has been established, especially in the management information system (MIS) section, in order to be able to explain the detailed evaluation criteria to the top management and the key users. As this stage is also the selection process that requires the courage of top management to make decisions, the commitment of the top management is very important in choosing the right key for each department that are directly related to the implementation of ERP modules.

The third stage is the project planning. The third stage is to implement the blue print of the company planning. In this stage, the ERP consultants and business process consultants determines the jobs to be carried out. Both consultants design the ERP module implementation process for all departments in the company. Then, the consultants and top management specify the implementation plan, the number of key users, the detailed schedule of each module and the relevant departments, and the deadline for completion of the project. The consultants build the blue print of the company's processes by identifying work procedures, checking instructions for each procedure and forms used, and analyzing the tasks and 
responsibilities. They have to organize the resources and appoint the people for the implementation process in each department. The human resources that will manage the ERP system in each department are called key users, who generally are managers of the departments. Each key user is assisted by two to three people as a user to perform some tests on the processes that match their day-to-day functions and activities. The fourth stage of the ERP implementation is to customize the package to the existing company system. At this stage, the ability and the engagement of the key users and consultants are necessary to ensure the process of implementing ERP.

Customization process is a very technical and detailed process per each module. In this process, the system adjustments are made by running the already made procedures, and revised to the ERP system. This process is a long process that requires high commitments from workers because they will mostly work overtime. The main function of the process is to implement ERP into a running system in the company so that the business processes and procedures can be understood and mapped as a solution that fits the company's goals. The company does not need to stop the operational process during the process of mapping or making of the blue print. Together with the ERP consultants and the business process consultants, the key users make system settings and system testing on the used modules.

The fifth stage is the enhancement of the key users' capability through the system adjustment process and training conducted by the consultants. This stage is a process to prepare and maintain the continuity of the ERP system in the company when the consultants leave the company after declaring the ERP system as going live. At this stage, it also conducts trials to determine the weaknesses and advantages of the system. The ERP system is tailored to the desired company process objectives by the company. At this stage, it is also necessary to increase the ability of the end users to help key users' jobs. The ability of the end users is accordingly to entry the data, record the processes that are run to fit the system, and provide training in groups in accordance with the responsibilities. This training is very important because the success of running ERP system is in the hands of these end users.

The sixth stage is stated by going live. In this process, the data base system is well organized, data entry system for all departments are well organized, data integration is also running well, the report required by all relevant departments have been well laid out. The consultants, along with the top management of the company, officially announce that the system is running well, and the older system is no longer running. This process is called as the kick off process. A research conducted by Nicolaou and Bhattacharya [15] reveals the impact of ERP post-implementation on the long-term financial performance in USA companies. This research states that the adoption of ERP in the company before and after some changes or revisions brings an impact on the financial performance of the company, so it is advisable to do the add-ons or upgrade the ERP version. The overall implementation process of ERP includes the soft and the hard aspects. Lewis et al., [16] state that the implementation of TQM in small and medium enterprises in Trinidad and Tobago is determined by the soft and hard aspects of the ISO 9001 implementation. A research by Gadenne and Sharma [17] states that the soft and hard quality in small and medium sized Australian manufacturing companies correlate with the organizational performance while implementing TQM. Another research conducted by Dubey [18] states that the soft quality management has a practical impact on the performance of the company. Based on the above explanations, then, this research has three main questions as follow: first, how far the soft ERP brings impact on the hard ERP; second, how big the impacts of soft ERP and hard ERP to the company integrated system; third, whether the company's performance is affected by soft ERP, ERP hard drive and integration system.

\section{Theoretical Research}

\subsection{Enterprise Resources Planning}


ERP is a system used by companies to perform data integration among departments in those companies. Some researchers define ERP as a system used by a company by setting up and deciding a software that can be used, when successfully implemented, to organize and integrate all application functions in the company, including marketing, cost accounting, finance, material management, warehouse management, maintenance, production planning, sales and distribution systems, human resources management and others [19]. ERP is also defined as a business software system package that conducts a real-time data integration in companies, in other words, a data entry of a department can be used by all connected departments [20].The implementation of project management, such as TQM, lean manufacture, information technology, and other projects, requires soft and hard ERP owned by the company. According to Gadenne and Sharma [17] the criteria of soft ERP are the top management philosophy, supplier support, employee training, and increased interactions among employees and customers. Meanwhile, the criteria for hard ERP are benchmarking and quality measurement, continuous Improvement, and efficiency for improvement. A research conducted by Lewis et al., [16] states that soft criteria include leadership, human resource management, suppliers' relations, and customer focus, while hard quality criteria include tools and systems that support the soft implementation. A research by Boon and Arumugam [21] states that soft TQM is practically related to human factors such as empowerment, training, commitment and education of employee. A research conducted by Kamiya et al., [22] states that soft computing is something that is done with computers that imitate human functions such as forecasting and scheduling, meanwhile, hard computing is defined as a well-structured process model, as well as an equipment that has accuracy and safety control.

A research conducted by Psomas et al., [23] states that the soft element of TQM is something that has a direct influence on quality improvement, such as leadership, organization skill and culture, empowerment, executive commitment, employee benefit, customer satisfaction and business performance, while for the TQM hard element is something that has no direct impact on quality improvements such as benchmarking, SPC (statistical process control) problem-solving tools. A similar research by Arvanitis et al., [24] states that soft ICT (information and communication technology) is personal, training, personal user, while hard ICT is equipment and capital for hardware development. A research conducted by Huang et al., [14] in Australia states that soft is defined as everything that is related to humans while hard is something that is related to technology and computer network.

Based on the definition of previous researchers, this research can define that soft ERP is anything related to or interacting with human when implementing ERP in the company, whereas the meaning of hard ERP is anything related to tools and equipment in the implementation of ERP or anything that has no direct impacts to the ERP implementation. When implementing ERP, the soft ERP may include commitment management [25]-[27], organizational culture [26], [28], [29], user and key users [6], [25], [27], [29], consultants or vendor [6], [29], training and education [1], [6], [27], [28]. Hard ERP during ERP implementation covers the long-term implementation [26] (Sun et al., 2005;), business process or blue print process [28], [29], package ERP or hardware and software [25], [28], implementation cost [25], [30], IT infrastructure [2], [25], [31].

\subsection{ERP Integrated System}

The consequence of ERP implementation is the entire system integration of data within the company into an information that can be used by all needed departments. Implementation stage in data integration process is how to collect the data for each department and build the system to interact data, build data base system, build data reporting system and summarize information, interpret data and use information in order to make right decision for company [32]. Internal integration is a process that serves to facilitate and speed up the data processing or data analysis within a company. Besides, the already processed data will be connected to all concerned departments so that they can be accessed quickly, easily, and practically. The 
internal integration focuses on activities within a company, which is a measure of how the company builds its strategies, practices, and processes into a collaborative and synchronized process so as to meet customer demands and interact with suppliers efficiently.

The concept of internal integration recognizes that departments and functional units within a company must act as a part of an integrated process. This insight is needed so that every process of supply chain flows (supplier process, company manufacturing process, company distribution process) can move in an integrated manner, so as to maximize the value of supply chain [33]. ERP system becomes the main thing for the basic system of transactions for supply chain management because it can make an integrated system in supply chain flow from suppliers to manufactures to distributors to agents or retailers even until customers through the customized hardware and software [34]. The integrated ERP systems can be measured through the accuracy data [1], [29], system stability [29], [35], system quality [29], and mutual understanding between department and team decision making [35].

\subsection{Business Performance}

The use of ERP system can provide many benefits, either directly or indirectly, to manufacturing companies. Yusuf et al., [26] state that ERP is a function of software application system that can help the organization in controlling the business better, because it can reduce the level of stock and inventory, increase stock turnover, reduce cycle time order, and improve productivity, which later create better communication and impact on increasing benefit (profit) company. According to Leon [36], ERP has some advantages, among others are lead-time reduction, timely delivery, cycle time reduction, better customer satisfaction, better supplier performance, and increased flexibility, reduction in quality costs, better resource utilization, improved information accuracy, and decision-making capabilities. General management principles relate business performance on profit, productivity, efficiency, effective, innovation, quality, and quality of work life [37]. ERP systems can be used to make some improvements to operational functions resulting in efficiency, effectiveness, data accuracy, data quality, decision-making capabilities, and customer satisfaction [38]. This study measures the business performance indicators that are generated from the implementation of ERP, such as efficiency, effectiveness, profit, data quality, decision-making ability, and customer satisfaction.

\subsection{Research Framework and Hypothesis}

The implementation of ERP at any company starts with the comprehensive understanding of the company's goals and objectives in implementing ERP; the management commitment in implementing ERP; the well-defined project planning, project schedule and resources used; adjusting the organizational structure and processes required during ERP implementation; building a reliable project team; provision of data and data integration; perform extensive training of key users and end users; measurement of performance in using ERP as a new system in the company, and customizing the implementation results to better suit the company [1], [36]. The implementation of ERP in the company cannot be separated from the human interaction which is called soft ERP, because of the many roles of management and users in implementing ERP. The most important thing is in the utilization of hard ERP to capture the large data and the data integration processes to provide precise and real time information. Both the role of soft ERP and hard ERP is necessary to integrate the correct data in order to facilitate decision makers in providing improved business performance. Improved business performance gives the company with the strength in winning the competition. Based on the previous explanation, the research framework (Fig. 1).

Based on the framework, there are some hypothesis constructed for this research: First hypothesis $\left(\mathrm{H}_{1}\right)$ : Soft ERP implementation bringing contribute impacts on the increased functions of Hard ERP implementation. Second hypothesis $\left(\mathrm{H}_{2}\right)$ : Soft ERP implementation bringing contribute impacts on the ERP 
system integration. Third hypothesis $\left(\mathrm{H}_{3}\right)$ : Hard ERP implementation bringing contribute impacts on the ERP system integration. Fourth hypothesis $\left(\mathrm{H}_{4}\right)$ : Hard ERP implementation bringing impacts on the business performance. Fifth hypothesis $\left(\mathrm{H}_{5}\right)$ : Soft ERP implementation bringing contribute impacts on the business performance. Sixth hypothesis $\left(\mathrm{H}_{6}\right)$ : ERP system integration bringing contribute impacts on the business performance.

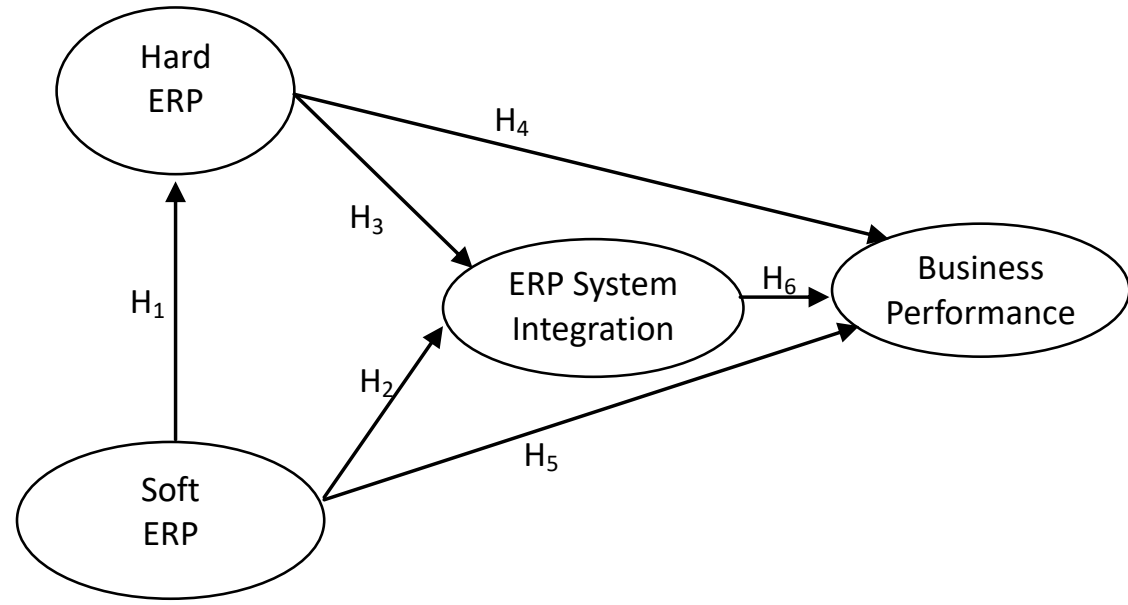

Fig. 1. Research framework.

\section{Research Method}

Data are collected from manufacturing companies in East Java that have implemented ERP by using consultants or vendors customizing ERP projects. The questionnaires are distributed to 100 manufacturing companies in East Java that have over 100 employees. The distribution of questionnaires is conducted by the team as they also do interviews on the implementation of soft and hard ERP factors. The respondents are at least the key users, who happen to be the head of each department. The measurement of each item is done with the likert scale, from strongly disagree with point 1 to strongly agree with point 5 . The variable of soft ERP is measuring the management commitment in implementing ERP and the organizational culture while implementing ERP. The variable of hard ERP is questioning the company blue print, the adequate ERP software packages, and the adequate company hardware during the ERP implementation, and the adequate funding for ERP implementation. Questions for the ERP system integration investigate the data accuracy on ERP system, the stability of ERP being used by the company, the quality of integration of the ERP, and the various work teams. For the variable of the company performance, the questions consist of the company efficiency as ERP is implemented, the company effectiveness when ERP is implemented, the company profits, and data quality after implementing ERP.

The returned and valid questionnaires are from 90 respondents, with the response rate of $90 \%$. The data processing is done with PLS (Partial Least Square). The latent variables in PLS consist of three relationships [39], the first one is the inner model or structural model, which observes the relationship between latent variables; the second one is called the outer model or often called measurement model, which seeks the relationship between the variables with the measurement items; and the third one is the weight relation which can estimate the relationship between the latent variables.

\section{Result and Discussions}

The questionnaires are distributed to manufacturing companies in East Java that have implemented ERP with a minimum number of 100 employees. The results of the respondent profiles from 90 returned 
questionnaires are summarized in the following Table 1.

Table 1. The Characteristic of the Respondents Based on Their Department and Working Time

\begin{tabular}{|l|c|}
\hline Department & Number \\
\hline PPIC & 4 \\
\hline Warehouse & 2 \\
\hline Finance & 17 \\
\hline Marketing & 19 \\
\hline HRD & 14 \\
\hline Logistics & 3 \\
\hline Accounting & 15 \\
\hline IT & 4 \\
\hline Production & 5 \\
\hline Purchasing & 7 \\
\hline Total Number & 90 \\
\hline
\end{tabular}

\begin{tabular}{|l|l|}
\hline Working time & Number \\
\hline 6-8 years & 18 \\
\hline 9-11 years & 23 \\
\hline 12-14 years & 15 \\
\hline $15-17$ years & 9 \\
\hline $18-20$ years & 7 \\
\hline $21-23$ years & 4 \\
\hline $24-26$ years & 2 \\
\hline $27-29$ years & 5 \\
\hline $30-32$ years & 4 \\
\hline$>33$ years & 3 \\
\hline Total Number & 90 \\
\hline
\end{tabular}

From Table 1, it can be observed that the departments that implement ERP are mostly marketing with SD (sales and distribution) module, production planning module, finance module, accounting module, and human resources module. It can be inferred that the manufacturing companies have implemented ERP, therefore, there is an integrated system among departments. The employees have been working for at least six years in the same company. This shows that the employees understand the company blue print or business process. All respondents have possessed the working experienced and expertise that are expected by the company.

Table 2. The Characteristics of the Respondents Based on Their Position in the Company

\begin{tabular}{|l|r|c|}
\hline \multicolumn{1}{|c|}{ Position } & Number & Percentage \\
\hline Owner & 4 & $4 \%$ \\
\hline CEO & 5 & $6 \%$ \\
\hline Manager & 37 & $41 \%$ \\
\hline Assistant Manager & 6 & $7 \%$ \\
\hline IT Coordinator & 2 & $2 \%$ \\
\hline Head of Department & 17 & $18 \%$ \\
\hline Financial Controller & 2 & $2 \%$ \\
\hline Supervisor & 12 & $13 \%$ \\
\hline Senior staff & 5 & $6 \%$ \\
\hline Total Number & 90 & $100 \%$ \\
\hline
\end{tabular}

Based on Table 2, many of the respondents are having the managerial position and the head of department, with the total of 54 respondents (90\%). It shows that the respondents are responsible for the ERP implementation as they can be the policy maker or the key users. Owner and CEO also contribute as many as $10 \%$ as the respondents. In several companies, the owners and CEOs are actively and directly involved in implementing the ERP system, therefore the management commitment is very obviously noticeable. The correlation between the indicator and the variable score with a minimum value of 0.5 is considered sufficient.

Based on the data processing with Java Web Start program, it is obtained from the cross load value that 
the indicator relation with variable value is the highest values in comparison to other indictors with other variables, and the value is above 0.5 (Table 3). This measurement is conducted to check the internal consistency from the indicators with the minimal value of 0.7. The composite reliability value of each variable is higher than 0.7 , therefore, they are acceptable. Composite reliability for soft ERP is 0,866 ; hard ERP is 0,852; ERP system integration is 0,840 and business performance is 0,916 .

Tabel 3. Cross Loading

\begin{tabular}{|c|c|c|c|c|c|c|c|c|c|}
\hline $\begin{array}{l}\text { Indicators } \\
\text { Symbol }\end{array}$ & $\begin{array}{l}\text { Soft } \\
\text { ERP }\end{array}$ & $\begin{array}{l}\text { Hard } \\
\text { ERP }\end{array}$ & Integrat. & Performa. & $\begin{array}{l}\text { Indicators } \\
\text { Symbol }\end{array}$ & $\begin{array}{l}\text { Soft } \\
\text { ERP }\end{array}$ & $\begin{array}{l}\text { Hard } \\
\text { ERP }\end{array}$ & Integrat. & Performa. \\
\hline $\mathrm{X} 11$ & 0.660 & 0.505 & 0.488 & 0.312 & Y11 & 0.409 & 0.666 & 0.370 & 0.453 \\
\hline $\mathrm{X} 12$ & 0.815 & 0.524 & 0.497 & 0.368 & Y12 & 0.480 & 0.779 & 0.737 & 0.533 \\
\hline X13 & 0.830 & 0.491 & 0.444 & 0.348 & Y13 & 0.374 & 0.726 & 0.405 & 0.386 \\
\hline $\mathrm{X} 14$ & 0.713 & 0.450 & 0.310 & 0.413 & Y14 & 0.296 & 0.715 & 0.540 & 0.302 \\
\hline $\mathrm{X} 15$ & 0.695 & 0.377 & 0.562 & 0.368 & Y15 & 0.467 & 0.702 & 0.643 & 0.445 \\
\hline X16 & 0.594 & 0.380 & 0.380 & 0.375 & Y16 & 0.464 & 0.664 & 0.414 & 0.225 \\
\hline Y21 & 0.464 & 0.575 & 0.756 & 0.458 & Z11 & 0.565 & 0.573 & 0.386 & 0.721 \\
\hline Y22 & 0.335 & 0.497 & 0.755 & 0.371 & $\mathrm{Z} 12$ & 0.456 & 0.485 & 0.417 & 0.815 \\
\hline Y23 & 0.461 & 0.599 & 0.843 & 0.366 & Z13 & 0.355 & 0.436 & 0.515 & 0.831 \\
\hline Y24 & 0.401 & 0.416 & 0.665 & 0.256 & Z14 & 0.405 & 0.538 & 0.489 & 0.796 \\
\hline \multirow[t]{2}{*}{ Y25 } & 0.186 & 0.243 & 0.540 & 0.158 & Z15 & 0.286 & 0.524 & 0.429 & 0.806 \\
\hline & & & & & Z16 & 0.408 & 0.514 & 0.567 & 0.842 \\
\hline
\end{tabular}

\section{Hypothesis testing}

Hypothesis testing for independent variables with dependent variables is called gamma coefficient and t-statistic value. If the t-statistic value is bigger or equal with 1.96, the hypothesis is accepted. If the t-statistic is less than 1.96, the hypothesis is rejected. The independent variable is the soft ERP, while the dependent variables are hard ERP, ERP integration system, and business performance

Table 5. Hypothesis Testing

\begin{tabular}{|l|c|c|c|c|}
\hline & original sample estimate & mean of subsamples & Standard deviation & T-Statistic \\
\hline Soft ERP -> Hard ERP & 0.643 & 0.671 & 0.108 & 5.945 \\
\hline Soft ERP -> Integration & 0.262 & 0.302 & 0.107 & 1.965 \\
\hline Hard ERP -> Integration & 0.439 & 0.539 & 0.173 & 2.533 \\
\hline Soft ERP -> Performa. & 0.281 & 0.301 & 0.139 & 2.028 \\
\hline Hard ERP -> Performa. & 0.375 & 0.370 & 0.130 & 2.895 \\
\hline Integration -> Performa. & 0.338 & 0.329 & 0.132 & 2.262 \\
\hline
\end{tabular}

The first hypothesis is the impact of soft ERP to hard ERP, and it is obtained that the value of gamma coefficient is 0.643 and the T-statistic is 5.945 (above 1.96), so it is significant. Creating soft ERP, especially in shaping the suitable organization's culture and increasing the competency of users and key users, is able to give a good performance to hard ERP in building business processes or blue print processes through 
customized ERP packages. This study also supports a research by Psomas et al., [23] that state soft TQM elements affecting hard TQM elements.

The second hypothesis, that states the impact of soft ERP to ERP integration system, gets the value of gamma coefficient of 0.262 , with the t-statistic value of 1.965 (above 1.96), so it is significant. The soft ERP brings a positive significant impact to ERP system integration. The soft ERP of building suitable organizational culture and increasing the competency of users and key users can increase the data accuracy and stable ERP system.

The third hypothesis testing, that states the impact of hard ERP to ERP integration system, gets the value of gamma coefficient of 0.439 , with the t-statistic value of 2.533 (above 1.96), so it is significant. The third hypothesis is accepted as the hard ERP brings a positive and significant impact to ERP integration system. The fourth hypothesis, that states the impact of hard ERP to the business performance, gets the value of gamma coefficient of 0.375 , with the t-statistic of 2.895 (above 1.96), so it is significant. The fourth hypothesis is accepted as hard ERP brings a positive and significant impact to manufacturing company's performance in East Java. The fifth hypothesis, that states the impact of independent variable of soft ERP to business performance, get the value of gamma coefficient of 0.281 , with the t-statistic value of 2.028 (above 1.96), so it is also significant. The fifth hypothesis is accepted as the soft ERP brings a positive and significant impact to the business performance. This research is in accordance to the research by Dubey [18] which states that soft TQM (human resource function, quality culture, relationship management with partners, information sharing, and visionary leaders) implementation brings a positive impact to the firm performance. This research also supports a research by Arvanitis et al., [24] which states soft ICT personnel and ICT training influences positively to the innovation performance. This research also is in accordance to the result of a research by Abdullah et al., [13] which states soft TQM factors bringing positive and significant impacts to the organization performance. The testing to the sixth hypothesis reveals that the ERP integration system brings impacts to the business performance, with the beta coefficient of 0.338 and t-statistic value of 2.262 (above 1.96), and it is significant. The sixth hypothesis is accepted as the ERP system integration brings a positive and significant impact to the business performance of manufacturing companies in East Java. Two factors of soft ERP and hard ERP bring positive and significant impacts to business performance. The hard ERP factors are related to the length of time in ERP implementation, blue print process, ERP packages, implementation costs, and IT infrastructure. Meanwhile, the soft ERP factors are about the management commitment, organizational culture, the competency of users and key users, consultants, and training. This research supports another research by Gadenne and Sharma [17] which states hard and soft TQM bring positive impacts to the firm performance. The impacts of the total independent variable of soft ERP to the company performance are obtained from direct impact and indirect impact with the total value of 0.706 .

\section{Conclusion}

Based on the result of the data process, the conclusions of this research are:

1) Soft ERP gives a positive and significant impact to hard ERP by building the suitable organization's culture and the competency of users and key users in creating business process or blue print process with ERP customized packages.

2) Soft ERP gives a positive and significant impact to ERP system integration by increasing the data accuracy and stable ERP system.

3) Hard ERP give a positive and significant impact to ERP system integration as making business process or blue print process with ERP customized package will increase the data accuracy and stable ERP system. 
4) Soft ERP gives a positive and significant impact to business performance as shaping the suitable organization's culture and increasing the competency of users and key users will increase the work effectiveness and company's profit.

5) Hard ERP gives a positive and significant impact to business performance as making business process or blue print process with customized ERP package will increase the work effectiveness and company's profit.

\section{References}

[1] Umble, E. J., Haft, R. R., \& Umble, M. M. (2003). Enterprise resources planning: Implementation procedures and critical success factors. European Journal of Operation Research, 146, 241-257.

[2] Xue, Y., Liang, H., Boulton, W. R., \& Snyder, C. A. (2005). ERP implementation failure in China: Case studies with implications for ERP vendors. International Journal of Production Economics, 97(3), 279-295.

[3] Aladwani, A. M. (2001). Change management strategies for successful ERP Implementation. Business Process Management Journal, 7(3), 266-275.

[4] Mashari, M. A., \& Zairi, M. (1999). BPR implementation process: An analysis of key success and failure factors. Business Process Management Journal, 5(1), 87-112.

[5] Drummond, P., Araujo, F., \& Borges, R. (2017). Meeting halfway: Assessing the differences between the perceptions of ERP implementers and end-users. Business Process Management Journal, 23(5), 936-956.

[6] Wu, J. H., \& Wang, Y. M. (2007). Measuring ERP success: The key-users "viewpoint of the ERP to produce a viable IS in the organization. Computer in Human Behavior, 23, 1582-1596.

[7] Park, J. H., Suh, H. J., \& Yang, H. D. (2007). Perceived absorptive capacity of individual users in performance of Enterprise Resources Planning (ERP) usage: The case for Korean firms. Information \& Management, 44, 300-312.

[8] Worley, J. H., Chatca, K. A., Weston, R. H., Aguirre, O., \& Grabot, B. (2005). Implementation and Optimisation of ERP systems: A better integration of processes, roles, knowledge and user competencies. Computers in Industry, 56(6), 620-638.

[9] Verville, J. C., \& Halingten, A. (2002). A qualitative Study of the influencing factors on the decision process for acquiring ERP software. Qualitative Market Research: An International Journal, 5(3), 188-198.

[10] Love, P. E. D., Irani, Z., \& Edwards, D. J. (2003). Learning to reduce rework in projects: Analysis of firm's organizational learning and quality practices. Project Manager Journal, 34(3), 13-25.

[11] Meredith, J. R., \& Mantel, S. J. (2004). Project Management a Managerial Approach 4/e. John Wiley \& Sons, Inc.

[12] Abdallah, A. B. (2013). The influence of "soft" and "hard" Total Quality Management (TQM) practices on total productive maintenance (TPM) in Jordanian manufacturing companies. International Journal of Business and Management, 8(21), 1-13.

[13] Abdullah, M. M. B., Uli, J., \& Tari, J. J. (2008). The influence of soft factors on quality improvement and performance: perceptions from managers. The TQM Journal, 20(5), 436-452.

[14] Huang, F., Gardner, S., \& Moayer, S. (2016). Towards a framework for strategic knowledge management practice: Integrating soft and hard systems for competitive advantage. VINE Journal of Information and Knowledge Management Systems, 46(4), 492-507.

[15] Nicolaou, A. I., \& Bhattacharya, S. (2006). Organizational performance effects of ERP system usage: The impact of post-implementation changes. International Journal of Accounting Information Systems, 7, 
18-35.

[16] Lewis, W. G., Pun, K. F., \& Lalla, T. R. M. (2006). Empirical investigation of the hard and soft criteria of TQM in ISO 9001 certified small and medium-sized enterprises. International Journal of Quality \& Reliability Management, 23(8), 964-985.

[17] Gadenne, D., \& Sharma, B. (2009). An investigation of the hard and soft quality management factors of Australian SMEs and their association with firm performance. International Journal of Quality \& Reliability Management, 26(9), 865-880.

[18] Dubey, R. (2015). An insight on soft TQM practices and their impact on cement manufacturing firm's performance: Does size of the cement manufacturing firm matter? Business Process Management Journal, 21(1), 2-24.

[19] Shehab, E. M., Sharp, M. W., Supramaniam, L., \& Spedding, T. A. (2004). Enterprise resource planning: An integrative review. Business Process Management Journal, 10(4), 359-386.

[20] Marnewick, C., \& Labuschagne, L. (2005). A conceptual model for enterprise resource planning (ERP). Information Management \& Computer Security, 13(2), 144-155.

[21] Boon, O. K., Arumugam, V., \& Hwa, T. S. (2005). Does soft TQM predict employees' attitudes? The TQM Magazine, 17(3), 279-289.

[22] Kamiya, A. Ovaska, S. J., Roy., R., \& Kobayashi, S. (2005). Fusion of soft computing and hard computing for large-scale plants: A general model. Applied Soft Computing, 5, 265-279.

[23] Psomas, E., Vouzas, F., \& Kafetzopoulos, D. (2014). Quality management benefits through the soft and hard aspect of TQM in food companies. The TQM Journal, 26(5), 431-444.

[24] Arvanitis, S., Loukis, E., \& Diamantopoulou, V. (2013). The effect of soft ICT capital on innovation performance of Greek firms. Journal of Enterprise Information Management, 26(6), 679-701.

[25] Soja, P. (2006). Success factor in ERP implementation: Lesson from practice. Journal of Enterprise Information Management, 19(6), 646-661.

[26] Yusuf, Y., Gunasekaran, A., \& Wu, C. (2006). Implementation of enterprise resources planning in China. Technovation, 26(12), 1324-1336.

[27] Woo, H. S. (2007). Critical success factor for implementing ERP: The case of a Chines electronics manufacturer. Journal of Manufacturing Technology Management, 18(4), 431-442.

[28] Mashari, M. A., Mudimigh, A. A., \& Zairi, M. (2003). Enterprise resources planning: A taxonomy of critical factors. European Journal of Operational Research, 146, 352-364.

[29] Zhang, Z., Lee, M. K. O., Huang, P., Zhang, L., \& Huang, X. (2005). A framework of ERP systems implementation success in China: an empirical study. International Journal Production Economics, 98, 56-80.

[30] Wang, E., Chou, H. W., \& Jiang, J. (2005). The impacts of charismatic leadership style on team cohesiveness and performance during ERP implementation. International Journal of Project Management, 23, 173-180.

[31] Huang, Z., \& Palvia, P. (2001). ERP implementation issue in advanced and developing countries. Business Process Management Journal, 7(3), 276-284.

[32] Malhotra, R., \& Temponi, C. (2010). Critical decisions for ERP integration: Small business issues. International Journal of Information Management, 30, 28-37.

[33] Flynn, B. B., Huo, B., \& Zhao, X. (2010). The impact of supply chain integration on performance: A contingency and configuration approach. Journal of Operations Management, 28(1), 58-71.

[34] Bose, I., Pal., R., \& Ye, A. (2008). ERP and SCM systems integration: The case of a valve manufacturer in China. Information \& Management, 45, 233-241.

[35] Yu, C. S. (2005). Causes influencing the effectiveness of the post-implementation ERP system. 
Industrial Management \& Data Systems, 105(1), 115-132.

[36] Leon, A. (2005), Enterprise Resources Planning. McGraw-Hill Publishing Company Limited, New Delhi.

[37] Cetindere, A., Duran, C., \& Yetisen, M. S. (2015). The effects of total quality managements on the business performance: an application in the Province of Kütahya. Procedia Economics and Finance, 23, 1376-1382.

[38] Gupta, M., \& Kohli, A. (2006). Enterprise resource planning systems and its implications for operations function. Techovation, 26(5/6), 687-696.

[39] Latan, H., \& Ghozali, I. (2013). Partial least squares konsep dan aplikasi path modelling menggunakan program XLSTAT-PLS, Semarang: Badan Penerbit Universitas Dipenegoro.

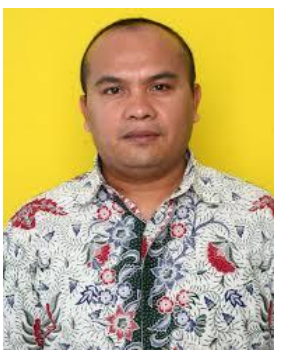

Zeplin Jiwa Husada Tarigan was born in 1974. He obtained his bachelor degree in electric and telecommunication engineering, and the master's degree in industrial management from Sepuluh Nopember Institute of Technology. He obtained his doctorate degree from University of Brawijaya, Malang, Indonesia. He has experienced as a manager in PPIC and BPO PP SAP R/3 in some manufacturing industries. At the moment, he is a full time faculty member at Petra Christian University, teaching in the Program Magister Management or Master's program. His research interests are ERP and operation management.

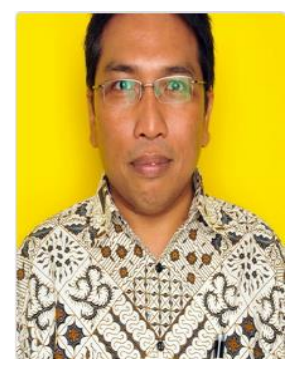

Sautma Ronni Basana was born in 1964. He obtained his bachelor degree in economics from Universitas Brawijaya, Malang, Indonesia, and his master's degree in economics from University of Indonesia, Jakarta, Indonesia. At the moment, he is preparing his dissertation for his doctorate degree in economics in University of Brawijaya, Malang, Indonesia. He is an associate professor on financial management in Petra Christian University, Surabaya, Indonesia. His research interests are financial management and ERP.

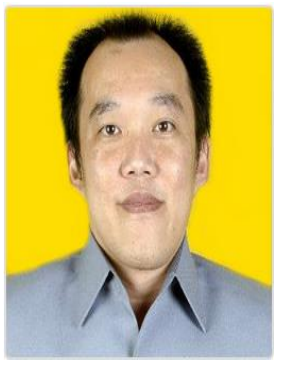

Widjojo Suprapto was born in 1967. He obtained his bachelor degree in English literature from Petra Christian University, Surabaya, Indonesia, and his master's degree in hospitality management from University of Nevada Las Vegas, USA. He devotes his experiences in the world of tourism, hotel, and restaurant. He is also a full time faculty member in Petra Christian University, Surabaya, Indonesia, teaching in the business management program. His research interests are hospitality supply chain management and Chinese family business. 